\title{
RESÍDUOS DE EQUIPAMENTOS ELETROELETRÔNICOS: A POSSIBILIDADE DE UM NOVO CICLO DE UTILIZAÇÃO COMO REVESTIMENTOS ARQUITETÔNICOS
}

\author{
Vanessa Koeler Gozzer \\ Instituto Federal de Ciência e Tecnologia do Espírito Santo - Campus Colatina \\ vkoeler@gmail.com \\ Giusilene Costa de Souza Pinho \\ Instituto Federal de Ciência e Tecnologia do Espírito Santo - Campus Colatina \\ giusilene.pinho@ifes.edu.br
}

Resumo: Os resíduos de materiais tecnológicos são crescentes no país e no mundo. Aumentando-se o consumo, aumenta-se também o descarte desses materiais, gerando uma grande necessidade de reuso e reciclagem. O presente estudo se trata de uma análise de viabilidade a respeito da utilização de Placas de Circuito Impresso ( $\mathrm{PCl}$ ) como revestimento arquitetônico. Como este é um material dentro do resíduo eletroeletrônico que se apresenta em forma de placa, como a maioria dos revestimentos na construção civil, o mesmo se torna propício ao estudo de sua reciclagem e transformação buscando esta aplicabilidade. Para tanto, foram realizadas investigações a respeito do lixo eletroeletrônico e da classificação do resíduo, para então ser possível a proposição de um material de acordo com características mercadológicas pertinentes a esta matéria prima. Além disso, as placas foram desmontadas e cortadas em bitola comercial de pastilhas de vidro e cerâmicas, $2,5 \times 2,5 \mathrm{~cm}$, de forma a aproveitar melhor as $\mathrm{PCl}^{\prime}$, que apresentam tamanhos diferentes, conforme sua função. Considerando a aplicabilidade e a produção de um material comercial, as peças foram organizadas de modo a seguir princípios de ordem como proporção, equilíbrio e unidade. Assim, foi avaliado também que as placas de circuito, como revestimento nesta e em outras dimensões, podem trazer inovação no design, visto que apresentam uma gama considerável de cores e tons, podendo ser mesclados de forma a se trabalhar com características ainda mais mercadológicas. O produto aqui apresentado pode contribuir tanto para a criação de alternativas quanto ao descarte de eletrônicos de pós-consumo, como para um novo conceito em design. Este enfoque pode levar o consumidor à proximidade com os conceitos de design sustentável, e assim, torná-lo também responsável por privilegiar materiais que apresentam essa proposta, dando uma maior visibilidade a questões ambientais e de resíduos.

Palavras-chave: resíduo eletroeletrônico, revestimentos arquitetônicos, placa de circuito impresso, design 